\title{
De escravo a doutor: Euzébio de Queiroz Coutinho Barcellos
}

\author{
Beatriz Ana Loner* \\ Miguel Angelo Vieira da Cunha Filho** \\ Ubirajara Soares Monteiro***
}

Resumo: Este artigo apresenta resultados de pesquisa sobre trajetórias de ex-escravos do extremo Sul do Brasil - parte de um detalhado esquadrinhar da sociedade pelotense e da comunidade negra urbana de Pelotas durante as décadas finais da escravidão e da Primeira República. O enfoque recai sobre os trabalhadores urbanos, livres, cativos ou libertos, suas lutas, organização e atividades durante a campanha da abolição e o primeiro período republicano. Acompanhando as trajetórias desse grupo, responsável pela formação de uma desenvolvida rede organizativa negra na cidade, foram encontrados elementos suficientes para traçar a biografia de alguns deles, dentre os quais se apresenta aqui a trajetória de Euzébio, escravo que trabalhou em uma charqueada e que, ao conseguir se libertar, em meados da década de 1880 , buscou novos rumos para sua vida, alcançando o posto de médico licenciado e reconhecimento pela sociedade.

Palavras-chave: pós-abolição; libertos; escravidão; curandeirismo, charqueadas.

\section{From slave to doctor: Euzébio de Queiroz Coutinho Barcellos}

\begin{abstract}
This article presents the results of a research on the trajectories of former slaves in the Brazilian south, part of a detailed picture of Pelotas black urban community during the last decades of slavery and in the First Republic. The focus is on the urban workers, free, enslaved or freed, their struggles, organizations and activities during the abolitionist campaign and the first republican period. Accompanying the trajectories of said group, responsible for forming a well developed black network in the city, were found enough elements to follow a biography on some of them, among which we present here a trajectory of Euzébio, a slave that worked in a charqueada and that, once he managed to free himself, in the mid 1880s, search for a new path in life, reaching the stance of licensed doctor and recognized by society.
\end{abstract}

Keywords: post-abolition, slavery, freedmen.

* Professora visitante da Universidade Federal de Santa Maria (UFSM).

** Licenciado em História pela Universidade Federal de Pelotas (UFPel) e professor da Escola La Salle Hipólito Leite.

***Graduando em História pela UFPel; Bolsista do Programa de Educação Tutorial (PET). 
Faleceu, ontem, o benquisto cidadão, nosso amigo Sr. Euzébio de Queiroz Coutinho Barcelos, médico licenciado, contando a avançada idade de 80 anos, viúvo e natural desse estado.

O corpo foi colocado em fina urna de madeira de lei, estilo francês, e ricamente guarnecido com emblema prateado e acolchoado com veludo roxo, e conduzido em carro de primeira classe, ao cemitério, onde ficou depositado na catacumba da Irmandade da Nossa Senhora do Rosário n. 49.

As cerimônias fúnebres tiveram lugar, com crescido acompanhamento, a cargo da casa Constantino Ribeiro.

O extinto gozava de geral apreço, sendo sua morte muito sentida.

A exma. família enlutada apresentamos sentidos pêsames. ${ }^{1}$

Esta simples notícia, publicada num dos maiores jornais pelotenses ao final da República Velha, pouco informa da extraordinária vida do falecido, o Dr. Euzébio Barcellos. O fato de ter posses lhe propiciou um rico enterro, mas a extensão do cortejo ficou por conta de seus relacionamentos, das sociedades de que participou durante sua vida e do respeito que mereceu na região. O resumido necrológio passou por cima de questões vitais para a reputação do doutor Euzébio, pois, por exemplo, não falou que ele fora membro do partido republicano na cidade, nem que era muito ligado à Igreja Católica. Claro que essas informações poderiam, em parte, ser deduzidas a partir da matéria jornalística. Afinal, o Diário Popular pertencia ao Partido Republicano Rio-Grandense, que governava o estado gaúcho há décadas. Quanto à Igreja Católica, a proximidade poderia ser facilmente deduzida da referência à irmandade, que consta no texto. E, sendo Irmandade do Rosário, nos leva a suposições sobre as tonalidades mais escuras da pele do doutor Euzébio, que o necrológio também houve por bem silenciar.

Mas a não informação sobre sua cor deve ser debitada na conta das práticas jornalísticas seguidas durante a Primeira República, com o sentido de não mencionar a cor de qualquer cidadão fora das páginas policiais, o que, aliás, só era feito se a pessoa não fosse branca. Numa sociedade racialmente misturada, partia-se do pressuposto de que a cor padrão fosse a branca e que outro tom de pele só merecesse destaque quando a conduta do indivíduo fosse desviante.

Ora, muito longe disso estava a conduta do Dr. Euzébio, católico praticante e muito chegado à hierarquia local da Igreja Católica, na qual atuou com denodo, tanto em irmandades quanto na consolidação de associações operárias católicas que desenvolvessem ideias de moderação e conformidade entre os trabalhadores, antes do que aquelas veiculadas pela Liga Operária e outras associações que possuíam caráter ateu e socializante. ${ }^{2}$

Por outro lado, o necrológio informa que era médico licenciado, ou, dizendo de outro modo, que teria licença para atuar como médico no estado, embora não fosse formado, uma peculiaridade das leis gaúchas, feitas sob forte influência da doutrina positivista. Desse modo, havia a possibilidade de que pessoas sem diploma, mas reconhecidas como curadores por aqueles que os procuravam, pudessem requerer licença para montar consultório e atender seus pacientes - exatamente desse modo que o Dr. Euzébio atuara. E era reconhecido, pois foi dessa forma que conseguira a maior parte dos imóveis e a fortuna que possuía antes de morrer.

Diário Popular, 07 jun. 1928.

2 Sobre as associações operárias e suas orientações ideológicas em Pelotas, ver: LONER, Beatriz. Construção de classe. Pelotas: EDUFPel, 2001. 
Mas, o que torna a sua vida tão interessante e extraordinária para os historiadores não está nesse necrológio ou em outros que porventura tenham sido dedicados a ele. O que o tornava tão excepcional pouco havia sido mencionado publicamente durante os últimos quarenta e oito anos de sua vida: ele nascera escravo, e nessa condição viveu toda a sua juventude. Essa era uma dimensão oculta de sua existência, a qual nunca se reportou depois de ter recuperado a liberdade.

Mas fora uma experiência marcante, pois debaixo da infame condição de escravo, ele nasceu e viveu, alforriando-se apenas com mais de trinta anos. Sem dúvida isso lhe trouxe marcas, tanto na educação quanto no modo de ver a vida e nos traços de seu caráter. A condição ${ }^{3}$ de escravo de charqueada pela qual passou não lhe tirou a ousadia - que o fez desfeitear publicamente alguns redatores e jornalistas brancos em 1916 —, nem a agência e a criatividade que demonstrou durante sua vida. E são essas exatamente as qualidades que interessam investigar neste artigo. Esse filho de africanos teve uma trajetória ímpar, que se conseguiu, em parte, desvendar, com a análise de múltiplas fontes, cartoriais e jornalísticas, embora alguns pontos ainda permaneçam sem esclarecimento.

\section{A origem na charqueada}

Quando morreu, Euzébio estava recolhido em casa, devido à avançada idade que lhe impedia de continuar a frequentar as associações de que gostava. Apesar disso, ainda estava à frente da Irmandade do Rosário, no cargo de diretor (no qual aparecia um significativo "Dr. Precedendo seu nome). ${ }^{4}$ Essa foi a entidade na qual mais constantemente ele se fez presente, desde seus tempos de cativo, e, de certo modo, ela representava as duas dimensões em que se apoiou em sua vida: a Igreja Católica, da qual era ativo participante, e a comunidade negra pelotense, na qual se criou e da qual foi respeitado membro.

Euzébio nasceu em 05 de agosto de 1848; era filho da "preta Ângela, ambos escravos de Cipriano Rodriguez Barcellos", como consta de sua certidão de batismo, datada de mais de um ano depois. ${ }^{5}$ Sua mãe aparece como nagô em alguns documentos, como em sua carta de alforria e nos batismos de alguns de seus filhos e, em outros, aparece como "de nação". Segundo Scherer, a maioria dos escravizados procedentes da África desembarcados ou presentes na vizinha cidade de Rio Grande, porto pelo qual entravam todos os cativos para o estado, eram minas, seguidos pelos nagôs. ${ }^{6}$ Reis afirma que as comunidades minas gaúchas eram numerosas e organizadas e que, para aquela província, o termo mina consistia num "guarda-chuva étnico", abrigando "nagôs, jejes, haussás e outros grupos importados dos portos do golfo de Benim"7, ou seja, para o estado gaúcho, os termos

3 Meillassoux, em Antropologia da escravidão, distingue entre estado e condição do escravo. Estado seria o fato de ser escravo, condição seria o uso que teria sua força de trabalho e, consequentemente, ele próprio, na sociedade que o escravizava. Ou seja, em alguns casos, embora o estado fosse o de escravo, a condição poderia ensejar uma melhor posição se constratada com outros que compartilhavam do mesmo estado. Consideramos essa distinção importante em relação à "sorte" de Euzébio e seus irmãos. MEILLASSOUX, Claude. Antropologia da escravidão. Rio de Janeiro: Jorge Zahar editor, 1995.

4 Jornal A Opinião Pública, Pelotas, 10 fev. 1928.

5 BISPADO DE PELOTAS. Livro 2 de Batizados de escravos de 1835 a 1852, folha 187, frente e verso, dia 13 de setembro de 1849.

6 SCHERER, Jovani. A nação da liberdade: os minas e outros grupos de procedência em Rio Grande (18101865). Comunicação apresentada no $3 .^{\circ}$ encontro "Escravidão e Liberdade". CD ROM. Anais do $3 .^{\circ}$ encontro "Escravidão e Liberdade". Florianópolis, UFSC, 2007.

7 REIS, João José. Domingos Sodré um sacerdote africano. São Paulo: Cia. das Letras, 2008, p. 260. 
mina e nagô às vezes podiam ser intercambiáveis. Ao final, sua origem africana será retomada, mas é melhor tratarmos de sua mãe agora.

Nascida por volta de 1828 , segundo a idade que aparece no Documento de Venda de 1862 (trinta e quatro anos) juntamente com todo o lote da charqueada em que vivia, provavelmente Ângela fez parte dos africanos escravizados ilegalmente, porque importados depois da lei de $1831 .^{8}$ Seu nome consta em algumas cartas de batismo dos anos de 1848 e 1849 como madrinha de outros africanos adultos do plantel de Cipriano que estavam sendo batizados, mas não se conseguiu descobrir seu assento de batismo nos livros da catedral São Francisco de Paula, em Pelotas. Talvez tenha sido batizada em outro local, tendo em vista que muitos charqueadores debandaram da cidade durante os anos da Revolução Farroupilha.

Quanto ao pai biológico, pouco se sabe. Quando se qualificou como eleitor, muitas décadas mais tarde, Euzébio informou ser filho de Cosme Rodrigues Barcellos, mas seguramente não era filho de algum branco. Na extensa genealogia de toda a família Rodrigues Barcellos, não consta nenhum Cosme, e Euzébio não era considerado mestiço, mas preto. Havia um cativo carpinteiro com esse nome no plantel de Cipriano, mas que teria cerca de quatorze anos, senão menos, quando do nascimento de Euzébio. Esse Cosme, também africano, libertou-se em 1868, por uma bela quantia9 e, provavelmente, é o mesmo que libertou Euzébio, anos mais tarde. Quanto aos seus padrinhos, consta que eram Manoel Redozino Vaz e Maria José da Porciúncula Vaz, casados e médios proprietários de terras em Jaguarão. ${ }^{10}$ Apesar disso, seja pela distância ou por falta de interesse, não parecem ter feito muito pelo seu afilhado.

Seu proprietário, Cipriano Rodrigues Barcellos, era dono de dois saladeiros em Pelotas, local em que sua mãe, e possivelmente seu pai, trabalhavam. O regime disciplinar das charqueadas, aliado à péssima higiene e à concentração do trabaIho em poucos meses, não deixava entrever muitas chances ao pequeno Euzébio. O trabalho extenuante em época de safra, iniciado à meia-noite e prolongado até parte da tarde seguinte era árduo, não poupava esforços e era feito de forma rústica, prejudicando o corpo e a saúde dos trabalhadores envolvidos em alguma de suas tarefas. Além disso, normalmente se prolongava de novembro a maio e era realizado à beira do rio, com calor e insetos no verão e frio cortante no outono, especialmente durante as madrugadas, momento em que se abatiam as reses. $\mathrm{Na}$ entressafra, esses trabalhadores eram empregados em olarias, em sítios e na construção civil, erguendo os palacetes de seus senhores no centro urbano da cidade."

Estabeleceu-se a existência de trinta a quarenta charqueadas ${ }^{12}$ entre $1780 \mathrm{e}$ 1890 , cada com vinte e nove a cem trabalhadores escravizados, sendo dispostas

8 Arquivo Público do Estado do Rio Grande do Sul (APERS). Documentos da Escravidão: Livro de Compra e venda de Escravos. Porto Alegre: Corag, 2010, v.2, p. 83. Documentos de venda de escravos de Cipriano Rodrigues Barcellos e Domingos Pinto França Mascarenhas a Cândido Barcellos e irmão, em 1/12/1862.

9 Arquivo Público do Estado do Rio Grande do Sul (APERS). Documentos da Escravidão: Catálogo Seletivo de Cartas de Liberdade dos Municípios do Interior. v. 1. Porto Alegre: Corag, 2006, p. 487. (Doravante relacionado como APERS, cartas de liberdade).

10 APERS. Inventário n. 617. Inventariado: Manoel Redozino Vaz, inventariante: Maria José da Porciúncula Vaz, ano de 1874, fundo Jaguarão.

11 Sobre as condições de trabalho nas charqueadas, ver: GUTIERREZ, Ester J. B. Negros, charqueadas \& olarias: um estudo sobre o espaço pelotense. 2.ed. Pelotas: Editora da UFPel, 2001, p. 185-191; COUTY, Louis. A erva mate e o charque. 2.ed. Pelotas: Seiva, 2000. Sobre as doenças que acometiam os seus trabalhadores, ver: LONER, B; GILL, L.; SCHEER, M. Enfermidade e morte: os escravos na cidade de Pelotas, RS, 1870-1880. História, ciência e saúde. Manguinhos, Rio de Janeiro, dez. 2012, v. 19, supl.1, p. 133-152.

12 Há uma certa divergência sobre seu número, constatada no Dicionário de História de Pelotas, organizado por Beatriz Loner, Lorena Gill e Mario Osorio Magalhães, primeira edição, Pelotas: Ed.UFPel, 2010. Verbetes: Charqueadas - autora Ester Gutierrez, p. 58 a 60 e Charqueadores- autor Mario Magalhães, p. 60 e 61. 
uma ao lado da outra, ao longo do Arroio Pelotas e da Costa do São Gonçalo. Dessa forma, o chamado sítio charqueador pelotense parecia propício a levantamentos de escravos, dos quais os senhores tinham muito medo, empregando rígida disciplina sobre os cativos, para evitar revoltas ou fugas. ${ }^{13}$ Se as primeiras não passaram de ameaças, as segundas foram constantes e contínuas, o que invalida qualquer suposição de um bom tratamento por parte dos senhores. Apenas se pode dizer que a alimentação desses trabalhadores seria mais rica do que dos cativos do restante do Brasil, devido ao farto uso da carne, especialmente miúdos e costelas de gado.

A charqueada que serviu de berço a Euzébio estava localizada na chamada Costa, na margem direita do arroio Pelotas, região hoje conhecida como Areal. Seu proprietário, Cipriano Rodrigues Barcellos, era membro de uma poderosa família, da qual vários irmãos se tornaram charqueadores na cidade. Por meio dos casamentos, os Rodrigues Barcellos mantinham laços entre si e com outros empresários do ramo, o que levava a um constante rearranjamento dos estabelecimentos saladerís e, logicamente, dos trabalhadores que elas continham. ${ }^{14} \mathrm{Em} \mathrm{1862,} \mathrm{Cipria-}$ no decidiu retirar-se da gerência ativa de seu estabelecimento, em prol da firma Cândido Barcellos e irmãos, da qual também fazia parte. ${ }^{15} \mathrm{Na}$ oportunidade, passou o lote de escravos de uma de suas charqueadas para a firma, em uma venda nominal a preço simbólico (cinquenta e seis escravos foram vendidos por apenas R 1:400\$) a seus sobrinhos, administradores da empresa. ${ }^{16}$

Essa venda possibilitou a visualização do conjunto completo de trabalhadores desse saladeiro: quarenta e seis cativos, entre os quais trinta e três homens, seis meninos e sete mulheres adultas. A não existência de meninas explica-se, em parte, pelo fato de que algumas foram alforriadas ainda crianças, como aconteceu com duas irmãs de Euzébio. ${ }^{17}$ Entende-se, pois, que essa transação consistiu apenas em uma troca de administração e de propriedade dentro da família Barcellos, portanto sem alterar a rotina diária, embora a entrada de mais dez trabalhadores e a eventual troca de capatazes e feitores trouxesse tensão e incerteza ao plantel.

Contando, também, com mais dez trabalhadores masculinos pertencentes a Mascarenhas, cunhado de Cipriano, a nova firma funcionou por alguns anos, mas

13 O fato de a fronteira com o Uruguai estar a pouco mais de cem quilômetros a pé das charqueadas, podendo também ser alcançada por barcos, era um incentivo às fugas individuais para fora do país. Durante a Revolução Farroupilha, muitos cativos foram levados pelos seus senhores para o Uruguai ou para fora do espaço charqueador pelotense, como meio de proteger seus "bens". Com isso, disseminou-se o conhecimento entre a escravaria, mesmo a africana, sobre a realidade diferenciada do Uruguai e os caminhos a serem palmilhados para as fugas. O Uruguai conseguiu extinguir a escravidão a partir de 1846, o que trouxe vários conflitos com estancieiros rio-grandenses, que possuíam terra nos dois países, obrigando o pequeno Uruguai a fazer várias concessões ao grande e escravocrata vizinho, especialmente durante os primeiros anos. Mas essa situação serviu para quebrar a continuidade do território sob domínio do escravismo, levando cativos do Brasil a buscar rotas de fuga para o Sul, para a liberdade além fronteira. PALERMO, Eduardo. Cautivos em las estancias de la frontera uruguaya. Trafico de escravos em la frontera oriental em la segunda mitad del siglo XIX. História em Revista, Pelotas, v. 16, dez. 2010, p. 7-24.

14 GUTIERREZ, Ester. Barro e sangue, mão de obra, arquitetura e urbanismo em Pelotas. Pelotas: Ed. da UFPel, 2004.

15 Idem. Negros, charqueadas \& olarias: um estudo sobre o espaço pelotense. 2.ed. Pelotas: Editora da UFPel, 2001. 16 APERS. Documentos da Escravidão, Livro de Compra e venda de Escravos. Porto Alegre: Corag, 2010, v.2, p. 79 e seguintes. Documentos de venda de escravos de Cipriano Rodrigues Barcellos e Domingos Pinto França Mascarenhas a Cândido Barcellos e irmão, em 1/12/1862. Cipriano e Domingos eram cunhados e Cândido Barcellos era sobrinho e afilhado do primeiro. A análise dos documentos demonstrou serem comuns "vendas" com valor baixo dentro das parentelas dos proprietários, provavelmente para não pagar taxas elevadas de transmissão de propriedade.

17 Heduviges, sua irmã, foi batizada em 21/12/1851 (Bispado de Pelotas, Livro 2 de batismo de escravos, folha 274) e alforriada em 17/04/1854 (APERS. Cartas de Liberdade. v. 1, p. 419). Sua outra irmã, Julia, foi liberta ao nascer. Ainda outras pequenas escravas de Cipriano também foram libertadas nestes anos, como Maria Dandá, parda, filha de Justina, cuja carta de liberdade foi passada em 31/07/1847 (Idem, p. 414). 
terminou indo à falência e deixando dívidas aos sócios. Em 1868, quando da liquidação da empresa, vinte e um desses mesmos trabalhadores foram vendidos para o comendador Domingos Faustino Corrêa, de Rio Grande, integrando um lote de trinta escravos, pelo preço total de R 33:000\$000. ${ }^{18}$

A família nuclear de Euzébio sofreu várias alterações com essas mudanças. Na primeira transação, de 1862, Euzébio tinha quatorze anos e já trabalhava como servente de charqueada. Ângela, sua mãe, havia conseguido sua alforria um pouco antes, embora condicionada à morte do senhor e com um ônus de $\mathrm{R} \$ 500,00 \mathrm{a}$ ser pago em prestações. ${ }^{19}$ Mesmo assim, ela foi arrolada como escrava em 1862, pois seu nome consta do lote da primeira venda. Esse equívoco foi desfeito no inventário de Cipriano Barcellos, em 1869, e ela foi considerada livre para todos os fins. Além dos três meninos, Ângela teve pelo menos mais duas filhas: Heduviges, liberta em 1854 com dois anos e meio e Júlia, alforriada ao nascer, em 1862, pelo seu padrinho, justamente um dos novos donos do estabelecimento. ${ }^{20}$ Esse apadrinhamento, e a liberdade conseguida no batizado, por Júlia, levam a pensar em um possível relacionamento entre Ângela e o novo senhor, Cândido Barcellos, que poderia ser o pai do bebê.

Ângela continuou a morar na casa do senhor, até a morte de Cipriano, em 1868. Cipriano teve o inventário de seus bens feito no ano seguinte, mas nele ainda constam referências à Ângela, como a legalização de sua situação de liberta e a compra de "onze covados de chita e um xale" para ela, que são deduzidos como despesas pelo inventariante. ${ }^{21}$ Portanto, sabe-se que ela seguiu morando na casa da charqueada até 1869, quando se perde sua pista.

A morte do senhor auxiliou alguns a conseguirem sua liberdade, como Cosme, com trinta e dois anos, carpinteiro, e Lino, quarenta anos, pedreiro. Ambos eram africanos, estavam presentes na venda de 1862 e agora, seis anos depois, conseguiam a alforria pela quantia de R 1:200\$000 o primeiro e R 1:350\$000 o segundo. A certidão de batismo de Lino foi feita em 1848, com ele já adulto, provavelmente ao chegar, o que significa que conseguiu dinheiro suficiente para sua alforria em vinte anos.

Não obstante a venda, Cosme e Lino continuavam ainda sob o domínio legal de Cipriano, pois as alforrias ${ }^{22}$ registradas um mês depois da morte deste último reportavam-se a ele. Cândido Barcellos e Cândido Alves Pereira, os novos donos, passaram as cartas de liberdade, referindo-se a esses escravos como tendo sido "recebidos de herança" do tio, Cipriano Barcellos. Assim, o documento da venda de 1862 foi contestado pelas próprias cartas de alforria, que reconheceram o direito de propriedade de Cipriano sobre eles. Essa situação corrobora a ideia de que a transação de 1862 foi apenas uma forma de legalizar o aporte de capital empatado nos trabalhadores escravizados na empresa, visto que Cipriano era o seu maior sócio.

O ano de 1868 foi aquele da venda do lote original para outro charqueador, significando o fim da atividade empresarial desse ramo da família Barcellos, o que abriu um momento de mobilização dos escravos com pecúlio, buscando libertarem-se, antes da passagem a um novo senhor. Foi nesse momento que Cosme,

18 APER. Livro de compra e venda de escravos. v. 2, p. 130 e seguintes.

19 APERS. Cartas de Liberdade. v. 1, p. 426. A carta foi redigida "devido ao bem que me tem servido e por ser mãe de três filhos: Euzébio, Teófilo e Domício".

20 APERS. Cartas de Liberdade. v.1, p. 427. Ela nasceu em 01/07/1862 e foi batizada um mês depois, em 27/08/1862, o que denota uma grande rapidez em legalizar a situação da criança. Compare-se com Euzébio, que foi batizado somente um ano depois de seu nascimento.

21 APERS. Inventário do comendador Cipriano Rodrigues Barcellos e sua mulher Rita Bernarda de Barcellos, n. 681 , ano 1969 , maço $42,1 .^{\circ}$ cartório de órfãos e provedoria, fundo Pelotas.

22 BISPADO DE PELOTAS, Livro 2 de Batismos de escravos, p. 121, data 5/3/1848. 
Lino e José conseguiram suas alforrias. Ângela, por sua vez, livrou-se da condicionalidade de sua liberdade, com a morte de Cipriano e deve ter ido viver com suas filhas já libertas na cidade. Restaram os irmãos, que tiveram diferentes destinos. Tudo indica que foram utilizados para pagamento de dívidas da firma com credores ou sócios, o que ocasionou a divisão familiar e sua dispersão entre outros senhores.

Os inventários da família Barcellos daqueles anos indicam que houve a falência do empreendimento saladeril e que restaram dívidas por anos a fio. Embora a maioria dos cativos que trabalhavam no estabelecimento tenham sido vendidos para pagar as dívidas, outros foram entregues a pessoas da família, dentro do acerto final de contas da empresa. Euzébio e seus irmãos devem ter passado por essa situação, pois não foram vendidos juntos com o lote, mas também não foram alforriados.

Domício teria provavelmente doze anos em 1868, quando da liquidação da firma, e não há nenhum documento da venda ou passagem dele a outro senhor. Apesar disso, oito anos depois, foi encomendado na catedral da cidade, o corpo de um escravo com esse nome, caracterizado como "preto, 18 anos de idade, desta província", trabalhador de charqueada, cujos donos, herdeiros de Antonio José Gonçalves Chaves, eram também aparentados com a família Barcellos. ${ }^{23} \mathrm{~A}$ causa do falecimento de Domício, “tuberculoses pulmonares”, é perfeitamente compatível com uma das principais doenças que afligiam os trabalhadores de saladeiros, visto as precárias condições de trabalho e as atividades serem realizadas em ambiente insalubre. Pelos dados do APERS, o único trabalhador escravizado que possuiu o nome de Domício, em todo o interior gaúcho ${ }^{24}$, foi o filho de Ângela. Se a raridade do nome não adiantou nada a Domício, pelo menos auxiliou a identificá-lo.

Já Teófilo parece ter sido mais afortunado. Era um bebê em 1862 e estava com sete anos em 1868, sendo muito pequeno para tarefas pesadas e, provavelmente, foi encaminhado para aprendizagem de alguma profissão na cidade. ${ }^{25}$ De fato, em 1881, encontrou-se um Teóphilo Antônio Gonçalves, participando de um grupo de apostas na loteria. Suas apostas foram pequenas, constavam apenas de cinco bilhetes e um quarto de um outro, comprados por vinte e seis participantes. Mas a situação era compatível com o fato de que todos os apostadores eram negros e, detalhe importante, tinham patronímicos que lembravam ativos charqueadores da região. ${ }^{26}$ Mais tarde, já com o nome acrescido de um "Barcellos", encontrou-se Teóphilo Gonçalves Barcellos na diretoria de duas associações negras. A primeira foi a associação mutualista Sociedade Progresso da Raça Africana, uma das duas únicas entidades negras da cidade que se reportavam à África em seu nome, sendo Teóphilo o presidente da diretoria provisória e Euzébio seu tesoureiro, durante

23 BISPADO DE PELOTAS, Livro 4 de registro de óbitos da Catedral de Pelotas, anos 1865-1887, fls. 217 verso, dia 8 de novembro de 1876 .

24 A saber, quatro livros de inventários, dois de alforrias, dois de compra e venda, um de testamentos e um de processos-crime. Infelizmente, o livro de batismos no qual constaria seu batizado foi roubado do Bispado de Pelotas há alguns anos.

25 Havia outros Teóphilos, entre eles o mais próximo seria um carneador trabalhando em estabelecimento da parentela dos Barcellos, mas a idade é incompatível, pois este teria vinte e quatro anos em 1872, enquanto o irmão de Euzébio seria um moleque de apenas doze anos naquele mesmo ano. Este outro aparece no inventário de Luis Teixeira Barcellos e sua esposa, o qual também foi sócio da firma Barcellos e irmão. O inventário traz cópia da folha de matrícula geral dos escravos em 1872, na qual está Teófilo, descrito como preto, vinte e quatro anos, solteiro, de filiação desconhecida e carneador, que foi comprado do Rio de Janeiro. APERS. Inventário de Dorothea da Fontoura Barcellos e Luís Teixeira Barcellos, autos n. 777, maço 46 , estante $25,1 .^{\circ}$ Cartório de Órfãos e Provedoria, ano 1873 , fundo Pelotas.

26 Jornal do Comércio de Pelotas, 15 set. 1881. Frequentemente, as apostas em loterias eram feitas em grupo, por associações informais, das quais o nome e os números do sorteio eram publicados pelos jornais, como garantia da compra. Nesta notícia, a própria ordem de aparecimento dos nomes aparenta respeitar uma gradação, pois os negros livres estão acima e os libertos, abaixo. 
Os anos de 1892 e 1893.27 Na Sociedade Beneficente Feliz Esperança, Teóphilo foi segundo tesoureiro em $1905 .^{28}$

Quanto a Euzébio, em 1868 já teria vinte anos e, provavelmente, uma profissão. Se tivesse continuado como servente na charqueada, poderia ter aprendido os ofícios de carneador, desossador, graxeiro, carpinteiro, ou ainda, marinheiro. Quando foi alforriado em 1882, ele exercia a profissão de carpinteiro, a qual devia ser muito rentável, visto que os carpinteiros escravizados estavam entre o grupo cujas alforrias custavam mais caro entre os cativos. Mas o mais importante é que essa profissão não exigia a presença constante na charqueada, permitindo ao trabalhador ter residência urbana, ou até trabalhar por sua conta, apenas entregando uma quantia acordada entre ele e seu senhor, semanal ou quinzenalmente, como renda devida a este.

A dedução que Euzébio não estava sujeito à rigorosa disciplina de trabalho das charqueadas quando adulto foi feita a partir de notícias de jornais que mostravam sua presença na cidade, mesmo na época de safra da carne, de novembro a maio. Durante os anos de 1880 e 1881, ele participou de agrupamentos de apostadores em loterias, alguns casuais, outros não, como este abaixo, no qual era o tesoureiro:

\title{
Associação Lotérica Feliz Lembrança:
}

\begin{abstract}
A grande loteria de São Paulo
A primeira turma, pertencem os bilhetes 19.7790 a 19.7799 . A segunda turma, os números 176196, 176197, 176198, 176199, 197758, 197759, 176200, 197758, 197759, 176200, 197760, 1977611197763. Os bilhetes acham-se depositados em poder do tesoureiro da associação, sr. Euzébio Barcellos.
\end{abstract}

Pelotas, 3/12/1880. C. e Silva, Secretário.29

Esta notícia refere-se ao grande prêmio da Loteria do Ipiranga, que provocou muito furor no país, com seu prêmio de mil contos de réis. Para participar do sorteio, todos queriam apostar o maior número possível de bilhetes e, como consequência, além de surgirem várias sociedades de apostas, algumas também se associaram entre si, como esta acima, que negociou um acordo com outras duas sociedades, cada uma com um valor diversificado para as apostas. Essas informações fazem pensar que, se Euzébio era encarregado da tesouraria da Feliz Lembrança naquele momento, isso significa que deveria ser rapidamente acessado pelos demais participantes, o que implica em estar estabelecido ou empregado em local fixo na cidade, de preferência no seu centro. Portanto, é indício seguro que não trabalharia na charqueada, pois os meses de dezembro e fevereiro, datas em que foi citado pelos jornais, constituem o auge da safra, quando a jornada laboral pode chegar até quinze horas por dia. Por outro lado, dificilmente uma pessoa submetida a esse ritmo de trabalho poderia ainda ser arrecadador de apostas pelas ruas da cidade.

Além disso, Euzébio estava presente em outras associações e instituições urbanas. Naquele mesmo ano de 1880, seu nome aparece na diretoria da Irmandade do Santíssimo Rosário de Nossa Senhora. ${ }^{30}$ Ainda escravo, ele participava como simples mesário, mas depois de liberto, teve importantes papéis na diretoria da irmandade e também na devoção de São Benedito.

27 Fontes: Jornal Diário Popular. 6 e 12 maio 1893.

28 Jornal A Defesa, Bagé, n.17, ano II, 21 nov. 1905.

29 Jornais: A Discussão, 26 fev. 1881 e Correio Mercantil, 07 dez. 1880.

30 Jornal do Comércio. Pelotas, 06 out. 1880. 


\section{De escravo a liberto}

Sobre os anos de juventude de Euzébio, incluindo sua troca de senhor, não se conseguiu outros dados. Em sua carta de alforria, consta que ele seria propriedade de Cosme Rodrigues Barcellos, que exercia a profissão de carpinteiro e que teria trinta e um anos na data de 26 de janeiro de 1883, quando foi libertado. Sua alforria foi concedida gratuitamente, "em atenção à estima e amizade que lhe tributo e por isso sem receber por esta liberdade a mínima retribuição pecuniária". ${ }^{31}$ É muito estranha a forma como está redigida essa carta, pois demonstra que havia relações muito diferentes entre os dois. Afinal, qual senhor diria ter um tributo de respeito em relação ao escravo? Essa situação desafiava a fórmula comum das manumissões e também as convenções sociais, pelas quais o escravo era liberto pela vontade de seu possuidor e devia sua liberdade, mesmo que paga, a ele, o que ampliava o aspecto de dádiva da libertação, e o entendimento desta como uma graça, uma mercê do senhor, pela qual o libertando deveria ser eternamente grato. ${ }^{32}$ Euzébio teria sido matriculado como escravo por Cosme, em 02/05/1882, sob o n. ${ }^{\circ} 2283$ da matrícula geral e n. ${ }^{\circ} 1$ da relação de seu proprietário, o que significa que deveria ser o seu único escravo, ou o mais antigo deles, segundo o que se observou das relações de matrícula.

Euzébio refere-se a seu pai como africano, o que Cosme efetivamente era, o colocando dessa forma em sua qualificação eleitoral, em 1890; contudo, esse termo pode ter outro significado, o de mestre, ascendente espiritual etc. Cosme era carpinteiro e essa também foi a profissão de Euzébio, que deve tê-la aprendido com ele na charqueada. A questão da paternidade biológica é difícil de averiguar, não só porque havia outros Cosmes cativos, em plantéis de outras charqueadas, como também devido ao já mencionado fato de que, Cosme, quando do nascimento de Euzébio, recém entrara na puberdade, a julgar pela sua idade na nota de venda e na alforria. Ângela, por seu lado, tinha vinte anos na ocasião e, provavelmente, muitos eram seus admiradores, mais fortes e com maior prestígio que o ainda adolescente Cosme.

Mesmo filho de um Cosme africano, resta a possibilidade de que Euzébio fosse liberto por outro Cosme, filho ou sobrinho do ex-proprietário Cândido Barcellos, mas é uma hipótese remota, pois não há registros de descendentes com esse nome entre as parentelas de Cândido ou de Cipriano, ou ainda na família extensa dos Rodrigues Barcellos. ${ }^{33}$ A utilização do sobrenome dessa família provavelmente adviria do fato de Cosme já ter sido escravo dos Rodrigues Barcellos e ter adotado esse patronímico.

Cosme, liberto desde 1868 , deveria ter se dedicado a sua profissão, talvez alugando os serviços de Euzébio para auxiliá-lo nos trabalhos de carpintaria e depois investindo em comprá-lo. Estes dois homens, com apenas quatorze anos de diferença de idade, passaram anos trabalhando em conjunto e devem ter desenvolvido uma forte amizade, levando o mais novo a considerar o mais velho como pai, o que fez oficialmente quando precisou declarar um nome paterno, para ter maior respeitabilidade, em um documento oficial que o instituía como eleitor, etapa importante de sua incorporação política na sociedade.

Nascido Euzébio, ele compôs seu nome utilizando parte do sobrenome do político Euzébio de Queiroz Coutinho Matoso da Câmara, ministro do Império entre 1848 e 1852 e, nesse cargo, autor da lei — que leva seu nome — que impediu

31 APERS. Cartas de Liberdade, v. 1, p. 555.

32 Ver: GRIMBERG, Keila. Liberata, a lei da ambiguidade. Rio de Janeiro: Relume-Dumará, 1994.

33 A investigação foi feita por meio dos vários sites de genealogia dessa família e também por: GUTIERREZ, Ester. Negros, charqueadas \& olarias. Op. cit. 
definitivamente o tráfico de escravos para o Brasil. Tudo indica que nascido dois anos antes da Lei Euzébio de Queiroz, aproveitou a coincidência de ter o mesmo prenome para incorporar ao seu, aquele do responsável pela lei que impediria, no futuro, que outros africanos fossem caçados na África e enviados para o Brasil como escravos. Ele não poderia saber que a escravização de seus pais foi facilitada pelo não cumprimento da lei anterior de 1831 , da qual o político acima também foi em parte responsável e, dessa forma, carregou durante toda a vida o nome daquele a quem considerava, equivocadamente, um benfeitor de sua raça. ${ }^{34}$

O outro sobrenome, Barcellos, veio de seu proprietário, quiçá do próprio Cosme, talvez o primeiro, Cipriano Rodrigues Barcellos. Nos primeiros momentos de sua aparição em jornais, ele é apresentado como Euzébio Barcellos, ou como Euzébio de Queiroz Coutinho, mas por fim, afirma-se com todo o seu nome, pelo qual deveria ser conhecido por todos na cidade.

Pelotas, a cidade na qual Euzébio estava começando sua vida livre, era uma das mais importantes do estado gaúcho, muito rica e frequentada devido aos negócios do charque, pois possuía um porto fluvial bem frequentado por navios, além de distar apenas $60 \mathrm{~km}$ do porto de Rio Grande, o que permitia muita interação com outras regiões. Seu comércio era muito forte e, nas duas décadas finais do século XIX, estava em processo de industrialização acelerado. Sua população estava dividida entre uma elite culta e educada, que cultivava as artes, a música e o teatro, e era composta de uma grande massa de trabalhadores, muitos dos quais estrangeiros, vindos à cidade como artesãos, ou estabelecendo-se nas colônias do município como agricultores. Sua população escrava, que já tinha se constituído em quase metade dos seus habitantes em meados do século, estava restrita a oito mil cento e quarenta e uma pessoas em setembro de 1873, e cinco mil novecentos e dezoito em julho de 1884.35 Logo a seguir, com a campanha da Emancipação (transformação dos cativos escravos em cativos contratados), esse número baixou significativamente, mas ainda em inícios de 1888 deveria haver por volta de dois mil escravos na cidade. ${ }^{36}$

Sabe-se que Euzébio, mesmo escravizado, já era reconhecido por parcela significativa da comunidade negra pelotense como pessoa de confiança (mesário de irmandade, tesoureiro de sociedade lotérica) e como liderança, tanto que fez parte da primeira comissão do Centro Ethióphico em outubro de $1884 .{ }^{37}$ Esse Centro foi criado pelos afrodescendentes para representá-los na campanha da emancipação de 1884 - no esforço de transformar todos os escravos em contratados com liberdade sujeita à prestação de serviços - , encaminhada pelos senhores como forma de terminar com a escravidão de forma moderada e gradual..$^{38}$

Neste cargo, como em outros posteriores, vai aparecer uma característica fundamental de Euzébio: sua ligação com a Igreja Católica, provavelmente um dos meios pelos quais ele mais se utilizou para ser reconhecido pela comunidade negra e obter o respeito dos brancos. Essa aliança esteve presente em toda sua vida, ini-

34 Sobre a atuação do político Euzébio de Queiroz Matoso, ver: CHALHOUB, S. A força da escravidão. São Paulo: Companhia das Letras, 2012.

35 Quadro demonstrativo da população escrava no município de Pelotas, província de São Pedro do R. S. de 30 de setembro 1873 a 30 de junho 1884. Correio Mercantil.Pelotas, 23 ago. 1884.

36 Dados sobre economia e sociedade do município de Pelotas e sua população no início da República estão disponíveis em: LONER, Beatriz. Construção de classe. Op. cit. cap. 1.

37 A Discussão. 17 jan. 1884.

38 Sobre os contratos, ver: MOREIRA, Paulo Roberto S. Faces da liberdade. Máscaras do cativeiro. Porto Alegre: EDIPUCRS, 1996. Sobre a organização negra na cidade, ver: LONER, Beatriz. Abolicionismo e imprensa em Pelotas. In: ALVES, Francisco (org.) Imprensa, história, literatura e informação. Rio Grande: EDFURG, 2007, p.57-64. 
ciada ainda enquanto escravo, com a participação em duas irmandades negras: a Irmandade de Nossa Senhora do Rosário, já citada e a Irmandade de São Benedito, que tinha menos recursos que a anterior. Quando livre, participou como juiz protetor e presidente em diretorias dessas irmandades, auxiliando ainda na fundação do Asilo São Benedito para crianças de cor e tomando parte em sua direção. ${ }^{39}$ Além de sua participação, sua esposa também pertencia à Irmandade de Nossa Senhora do Rosário, sendo eleita juíza das festividades em $1888.4^{\circ}$

Como liberto, pôde associar-se e participar da diretoria da Sociedade Mutualista Fraternidade Artística, sociedade de artesãos afrodescendentes que não aceitava escravizados. Essa sociedade estava muito ligada a Manoel Conceição da Silva Santos, grande liderança negra católica e abolicionista, também sócio da Irmandade do Rosário, e com quem Euzébio vai compartilhar ainda outras diretorias de sociedades recreativas no futuro. A prova de sua respeitabilidade entre os pares é que, no ano de 1890, quando há uma crise na entidade, ele e um dos filhos de Manoel da Conceição são indicados para a junta governativa daquela associação. ${ }^{41}$ Outra prova de seu prestigio, ainda como escravo, é o fato de que apadrinhou quatro ingênuos, entre os anos de 1881 e 1884, quando cessaram os registros de batismo de escravos na matriz de São Francisco de Paula. ${ }^{42}$

Já vimos que também esteve presente na Sociedade Progresso da Raça Africana, como tesoureiro, entre 1891 e 1893.43 Essa sociedade demonstra que havia, entre alguns afrodescendentes, a preocupação de não esquecerem suas origens africanas, o que é um fato singular para aqueles anos, pois consultando a lista de sociedades da comunidade negra pelotense no período republicano, torna-se evidente que a identidade dos afrodescendentes trilhava outra direção, buscando a integração na sociedade brasileira como trabalhador nacional, silenciando sobre sua situação anterior. Filhos do Trabalho, Recreio Operário, Fraternidade Artística, Satélites do Progresso, enfim, a própria denominação de seus clubes não lembrava sua cor, ou suas origens, sendo esta associação uma das duas únicas exceções a esse quadro, assinalando uma característica especial de seus membros, que talvez fossem todos minas, ou então trabalhadores de charqueada.

Deve ter sido no período da juventude, ainda como cativo, que aprendeu danças e bailados variados, ensino das quais, depois de livre, foi seu ganha-pão por muitos anos e lhe trouxe prestígio e reconhecimento entre a fina flor dos moços brancos da cidade. Esse aprendizado pode ter sido feito na própria cidade, ou ele pode ter acompanhado seus senhores até o Uruguai e lá tomado conhecimento de novas danças, que depois trouxe à cidade. ${ }^{44}$

Outra preocupação de Euzébio foi com a educação. Assim, temos esse carpinteiro de trinta e oito anos matriculando-se, em 1886, nos cursos noturnos da

39 Lembrando novamente que só se conseguiu saber algumas diretorias dessas irmandades, Euzébio teve participação na Irmandade do Rosário como mesário (J. Comércio, 06 out. 1880) e como presidente (A Opinião Pública, 10 fev. 1928), na devoção de São Benedito em 1909, como juiz protetor (Livro de atas da Devoção de São Benedito). No Asilo, ele participou como diretor em 1909 e 1911 (A Opinião Pública, 31 mar. 1909 e Diário Popular, 14 abr. 1911).

40 Jornal Onze de junho, 13 nov. 1888.

41 Correio Mercantil, 24 ago. 1890. Mas logo a seguir, chama-se eleição e ele fica apenas na Comissão de contas.

42 BISPADO DE PELOTAS, Livro 8 de Batismo de Escravos, anos 1879 a 1884, folhas 25, 31, 36 e 37. As mães de cada uma das crianças eram escravas de diferentes senhores.

43 Diário Popular, 06 maio 1893.

44 Conforme sua declaração, inserida no Jornal O Rebate, 26 set. 1916. Durante pesquisas anteriores, anúncios e notícias sobre sua sociedade de dança já haviam sido encontrados nos jornais, mas não anotados, porque nada indicava sua origem escrava e operária e o foco do interesse eram os proletários pelotenses. 
Biblioteca Pública Pelotense, muito frequentado por ex-cativos como ele. Nesse momento, como em vários outros, não é informada sua filiação e tudo indica que deve ter estudado por poucos meses, pois não se rematricula e não há outros apontamentos a respeito. ${ }^{45}$ Entretanto, deve ter aprendido a ler e a escrever, pois sabia assinar seu nome, demonstrando, mais tarde, ser leitor de obras religiosas. Ele vai preocupar-se em dar boa educação à sua filha Marina, o que não era comum em inícios do século XX para mulheres.

Ao se matricular na escola da biblioteca, ele constou como solteiro, mas deve ter casado mais ou menos por esta época, pois sua única filha nasceu em agosto de 1886 aproximadamente. Sua esposa, Margarida Dias Barcellos, já possuía três filhos e há fortes indícios de que tinha sido escrava, bem como sua primeira prole. Um de seus filhos, à época de seu inventário, tinha paradeiro desconhecido, e os outros dois eram analfabetos, em contraste com a educada letra de Marina, o que é prova evidente do investimento em sua educação.

\section{Trabalhador livre no período republicano}

Talvez a República não tenha trazido muitas modificações ao cotidiano de Euzébio, pelo menos não maiores do que as transformações em sua vida pessoal, devido ao casamento e ao nascimento de sua filha, o que aconteceu em data entre 1885 e 1886 . Mas sua esposa faleceu cedo, em 16 de outubro de 1903 , e ele teve que fazer um inventário. Assim, sabe-se que, em 1904, seus bens constavam apenas de um terreno rural, comprado em maio de 1898 e avaliado em 250 mil réis. Embora as dívidas contraídas com o enterro da falecida e uma pesada conta de farmácia superassem em muito esse valor, o bem não precisou ser vendido, pois Euzébio assumiu o pagamento das dívidas e o imóvel ainda constava entre seus bens quando de sua morte. ${ }^{46}$ Ressalte-se que seu trabalho como dono da escola de dança e professor deveria render-lhe bons proventos, embora provavelmente não devesse ser o único, como ficará claro mais tarde. De todo o modo, seu patrimônio crescerá bastante até sua morte, em parte graças à rede de amigos e de clientela política de que participou.

Euzébio cuidou de ter participação na vida política e era eleitor, qualificandose nos alistamentos eleitorais de 1890 e 1900, nos quais constou como casado e artista, filho de Cosme Barcellos. ${ }^{47} \mathrm{Em}$ todos os demais documentos, não há menção ao nome dos genitores. Mas utilizar o nome paterno na qualificação eleitoral significava mais um passo no sentido da conquista do respeito da sociedade, pois, ordinariamente, quando os pais não eram casados, constava apenas o nome da mãe.

Ele não só se qualificou como eleitor, mas também era filiado ao PRR, Partido Republicano Rio Grandense, que governou o estado até 1930. Em 1916, quando polemiza pelos jornais com detratores, ele invoca essa condição como um símbolo de seu status social e uma advertência a seus inimigos: "Como cidadão brasileiro, filiei-me ao pujante Partido Republicano, desde a sua fundação". ${ }^{8}$ Nisso, seguiu

45 Arquivo Histórico da Biblioteca Pública Pelotense, livro de matriculados nos cursos noturnos desta Instituição, p. 49. Agradeço à Mariana Couto Gonçalves pela cópia da informação, a qual foi negada o acesso a dois dos autores.

46 APERS. Processo n.1175. Inventário de Margarida Dias Barcellos, inventariante: Euzébio de Queiroz Coutinho Barcellos, fundo 48, Comarca de Pelotas, ano 1904.

47 Respectivamente, A Pátria, 07 jul. 1890 e Diário Popular, 03 maio 1900.

48 Jornal O Rebate, 26 set. 1916. 
a trajetória de muitos artesãos da cidade, brancos ou afrodescendentes, que se filiaram a esse partido ainda em seus inícios, devido ao papel que a agremiação representou na campanha abolicionista no estado e as esperanças de cidadania, igualdade e melhoria das condições de vida associadas ao republicanismo em seus primeiros anos no Sul. Deve-se ainda assinalar que havia pouca opção partidária dentro do limitado sistema eleitoral da época e que pertencer ao partido do governo trazia benesses importantes, especialmente para quem tinha desvantagens nítidas, expressas na cor da pele e na origem social. ${ }^{49}$

A partir do início do novo século, cessam-se as notícias sobre ele nos jornais, o que significa que diminuíram suas participações nas diferentes entidades. Deveria estar trabalhando bastante e dedicando-se a amealhar bens, entre eles propriedades, que lhe permitissem uma vida tranquila na velhice e deixassem sua filha amparada. Entretanto, continuou a prestigiar e participar ativamente das associações vinculadas à Igreja, entre elas as irmandades e o asilo, já comentados. Ao lado disso, teve participação em instituições de comunidade negra, recreativas ou políticas.

Dessa forma, mesmo idoso, aos setenta e seis anos de idade, participou em posição de destaque, na fundação e no desenvolvimento da Associação Centro Cívico Alcides Bahia, que tinha por objetivo "defender os interesses da raça etíope". Desse modo, inicia seus trabalhos enviando telegrama ao presidente Arthur Bernardes, protestando contra a tentativa de depuração do deputado Alcides Bahia, eleito pelo Amazonas, a pretexto de ser negro..$^{\circ}$ Vitoriosos, tiveram a visita de agradecimento do deputado à cidade.

Pelo seu inventário, chega-se à conclusão de que Euzébio investiu todo o dinheiro conseguido na compra de residências na rua Marques de Caxias, especialmente na quadra em que morava. Nessa rua, Ihe pertenciam os prédios 460, 468 e 470 e na rua 24 de fevereiro, os prédios 301 e 303. Compunha a herança, ainda, um prédio na mesma Marques de Caxias, mas fora de alinhamento e um terreno na estrada para Monte Bonito. ${ }^{51}$ Na polêmica enfrentada por Euzébio com os redatores do jornal O Dia, em 1916, sua casa foi descrita como "muito confortável, debaixo de vários pontos de vista" e com um padrão de mobiliário de classes médias altas, contando inclusive com gramofone, novidade naqueles tempos. ${ }^{52}$ Ao morrer, deixou um total de sete imóveis. Defendia seus interesses comerciais como qualquer outro proprietário, como quando entra com ação de esbulho contra a moradora antiga de uma casa que recém comprara. ${ }^{53}$

Como pai de família, preocupou-se com que sua filha frequentasse as sociedades negras da cidade, zelando para que sua família se integrasse à comunidade negra pelotense e para que sua filha encontrasse parceiros matrimoniais dentro do grupo. Ele e a filha parecem ter sido muito próximos, pois mesmo depois de casada, era na casa do pai que ela comemorava seus aniversários, como em 1916, quando houve festa "com animado baile" 54 .

49 Sobre as relações dos trabalhadores negros e brancos com os partidos na cidade, ver: LONER, Beatriz. Construção de classe. Op. cit., cap. 7.

50 Jornal O Libertador, 25 abr. 1924.

51 APERS. Inventário n. 137, ano 1928. Inventariado: Euzébio Coutinho Barcellos, inventariante: Marina de Barcellos Araújo. Fundo 48, Pelotas. Note-se que o inventário fala realmente de prédios, ou seja, edificações, mas não as detalha, como era o comum em outros inventários.

52 Jornal O Dia, Pelotas, 25 set. 1916.

53 APERS. Processo de esbulho n. 521, ano 1921, fundo Pelotas Ré: Rosa Farias, suplicante: Euzébio Coutinho Barcellos.

54 Jornal A Alvorada, Pelotas, 13 ago. 1916. 
Marina, em sua juventude, esteve presente na ala feminina de algumas diretorias de sociedades recreativas negras, em diretorias de mulheres, dedicadas a promover festas e quermesses, como em 1908 e 1909 na sociedade bailante e carnavalesca Flores do Paraíso, que reunia os negros com maior vinculação à Igreja Católica. ${ }^{55}$ Em 1909, participou da Sociedade de Socorros Mútuos Princesa do Sul, como oradora, e do Grupo das Serpentinas, bloco ligado a Flores do Paraíso, já então utilizando o sobrenome de seu primeiro marido ${ }^{56}$, Rodolpho A. de Jesus. Mais tarde, casou-se com Manoel Francisco da Silva Araújo, foguista, e desquitou-se em 1929, pouco após a morte do pai, quando contava com quarenta e um anos de idade. Observe-se que o desquite não era comum naquele tempo, trazendo o repúdio social para as mulheres nessa condição. Talvez por esse motivo ela tenha vendido a casa que morava em 1932 e abandonado a cidade, estabelecendo-se em Porto Alegre.

Sem dúvida, Marina herdou do pai a coragem de enfrentar e vencer situações adversas. Mas ela estava preparada, ao menos financeiramente para isso, pois herdara uma casa avaliada em $12 \$ 000.000$, além de outros seis imóveis ${ }^{57}$, o que deve ter sido suficiente para lhe garantir uma vida confortável e lhe permitir tomar atitudes ousadas, como o desquite.

\section{De curandeiro a doutor}

O episódio que levou Euzébio a virar doutor, ou seja, médico licenciado e com placa na porta, é ilustrativo pela maneira como ele se colocava frente à vida, aceitando os seus desafios e procurando vencê-los dentro do que era considerado legal e aceitável pela sociedade. Tudo começou com uma figura bem relacionada em Pelotas, o Dr. Antônio Gomes da Silva, branco, juiz, advogado, com pretensões literárias, cuja vaidade era maior do que seus talentos e cujas obsessões o levaram ao descrédito.

Gomes da Silva arrendou o jornal A Opinião Pública, de 1913 a 1915, e lhe imprimiu seu estilo. Figura singular e narcisista, queria ser reconhecido pelos seus talentos teatrais e literários, sendo anticlericalista ao extremo, motivo pelo qual até hoje é posicionado por alguns cronistas e historiadores desavisados entre os militantes anarquistas da cidade. Realmente, envolveu-se com a Liga Operária da cidade, auxiliando a fundar um Centro de Estudos Sociais. Porém, em pouco tempo, suas ideias chocaram-se com aquelas dos libertários operários da Liga, os quais cortaram suas pretensões de organizador e articulador de eventos na entidade, ridicularizando suas propostas e denunciando a postura conservadora e subserviente aos poderosos que imprimia a seu jornal..$^{58}$

Gomes da Silva, então, voltou-se a outra de suas obsessões e envolveu-se em desastrada campanha com sátiras à Igreja Católica e às autoridades eclesiais da região, em artigos em verso e prosa contra o bispo. Rimada, sua poesia satírica é até divertida de ser lida hoje em dia, não foi assim considerada na época, pois o Bispo Ihe lançou a excomunhão. Também ordenou a devolução do jornal e o rompimento das assinaturas a todos os fiéis, sob risco de excomunhão. A viúva proprietária

55 Jornal A Alvorada, 05 dez. 1908, citado em 04 dez. 1954 (coluna Coisas do passado).

56 Jornal A Opinião Pública, 13 mar. e 26 maio 1909.

57 APERS. Inventário de Euzébio de Queiroz Coutinho Barcellos, inventariante: Marina Barcellos de Araújo, autos n. 137, ano 1928, fundo 48, Pelotas.

58 Ver a respeito: LONER, Beatriz. Construção de classe. Op. cit. 
do jornal, católica e aflitíssima com a perda de prestígio do órgão, exigiu imediatamente o fim do arrendamento. Gomes da Silva perdeu apoios e teve o desgosto de comprovar a eficácia dos aparatos repressivos da Igreja Católica até sobre uma população que não era muito crente, mas tinha medo de radicalismos, de ambos os lados. ${ }^{59}$

O jornal O Dia iniciou suas atividades em janeiro de 1916, com Gomes da Silva e seus novos sócios comprando equipamentos do antigo Correio Mercantil, que deixara de ser publicado recentemente. A nova empresa jornalista era composta, em termos de editoria e redação, por João C. de Freitas, como diretor gerente, e J. F. Villarinho, como redator. Freitas era riograndino, e, como jornalista, trabalhou em O Estado, Correio Literário, A Luta, e Echo do Sul (em sua cidade natal). Em Pelotas, posteriormente, vai trabalhar no jornal O Libertador, opositor ao PRR. ${ }^{60} \mathrm{Como}$ dramaturgo, deixou várias obras, entre elas a peça anticlerical "Os Solteiros". Pelo pouco que se sabe, Villarinho, o único pelotense, era jornalista e tipógrafo na cidade. Dos outros dois, há notícias de que acumulavam escândalos e/ou posições críticas ao governo republicano e à Igreja, o que deixava o jornal em posição difícil para se consolidar na cidade.

A apresentação gráfica do jornal pretendia inovar e apresentava uma coluna para a colônia alemã da cidade. Naquele momento, havia vários outros jornais na cidade: o situacionista Diário Popular, A Opinião Pública (que continuou a ser publicado, com novos arrendatários) e O Rebate, consolidado jornal de denúncias e oposicionista ferrenho do governo. A cidade, sem dúvida, comportava mais um jornal, mas O Dia ainda precisava se firmar. Durante aquela década, várias outras iniciativas jornalísticas tinham fracassado, pois era necessário conseguir assinantes e estabelecer-se entre os anunciantes, tarefa tanto mais difícil para O Dia, quando ainda repercutiam os ecos da campanha fracassada contra a Igreja e todos sabiam que o jornal também pertencia a Gomes da Silva. De todo o modo, nada mais se veiculou diretamente contra a Igreja Católica.

Como estratégia de inserção jornalística, O Dia passou a veicular reportagens de denúncia sobre variados problemas da cidade. Em setembro de 1916, este jornal iniciou a propaganda de um novo assunto ${ }^{61}$, com uma série de anúncios, espicaçando a curiosidade popular com a promessa de denúncias fantásticas e escandalosas, nunca completamente reveladas, de forma a manter o suspense para a reportagem do dia seguinte, quando, então, as escabrosas revelações aconteceriam. Ateu convicto, mas escaldado com a surpreendente conformidade dos pelotenses aos desígnios do bispo, dessa vez Gomes da Silva pensara ter encontrado inimigos mais frágeis, colocando sob sua mira os feiticeiros, curandeiros, as aborteiras e os demais praticantes de medicina popular da cidade, todos englobados sob o rótulo de "patifes lombrosianos" e outros epítetos discriminatórios. Provavelmente, tentava-se, por meio desse viés, criticar e ridicularizar a religiosidade popular, as crendices etc.

Assim, o jornal colocou um repórter na cola desses "charlatãs" (sic), o qual se passou por um cliente aflito e foi procurar os principais curandeiros da cidade.

59 LONER, Beatriz. Jornais pelotenses diários na República Velha. Ecos Revista, v.2, n.1, Pelotas: Educat, abr. 1998, p. 5-34.

60 Freitas (1880-1950) também era advogado, filólogo, literato e teatrólogo. Dados retirados de ALVES, Francisco das Neves. O partidarismo por opção discursiva: o Echo do Sul e seu discurso político partidário. Rio Grande: Furg, 2001, nota 31.

61 As reportagens de O Dia encontram-se neste mesmo jornal dos dias 09 de setembro de 1916 até 10 de outubro do mesmo ano. 
Dessa forma, tentava redimir-se do vexame anterior e conseguir nova credibilidade, como austero moralizador dos costumes e da vida pelotense. De quebra, poderia talvez respingar na própria Igreja Católica, como a culpada por não esclarecer seus fiéis sobre a doutrina cristã, tornando-os presas fáceis de charlatões que envenenavam sua saúde e sua paz de espírito, enquanto os depenavam de dinheiro e bens. Esse era, grosso modo, o apelo cotidianamente utilizado nas manchetes do jornal, que tentava chamar a atenção das autoridades para as ações criminosas desses "intrujões" ou "espertalhões", explicando em quais delitos criminais estariam incursas suas práticas e interpelando os delegados e homens da lei para que "cumprissem seu dever". Não se pode deixar de observar, aqui, uma tentativa também de cutucar a administração do PRR municipal, que não tomava providências contra essa exploração da crendice alheia e não cumpria seu papel.

O repórter inicia sua expedição aos "antros» ou «templos da perdição", indo, disfarçadamente até os pretensos feiticeiros e adivinhas, alegando precisar de seus cuidados profissionais. Em reportagens diárias, descrevia as práticas observadas, tais como as consultas e as prescrições curativas, em linguagem extremamente preconceituosa do ponto de vista racial, pois todos os três supostos feiticeiros eram afrodescendentes. Como "provas cabais" contra eles, o repórter comprava e o jornal dizia mandar para análise em laboratório químico o conteúdo das beberagens que eram entregues como receitas aos males que o jornalista dizia sofrer.

Entre os primeiros três denunciados estavam dois homens e uma mulher, todos negros ou mulatos. A "bruxa" Constantina é descrita como parda, com cerca de cinquenta anos. Especialista em poções amorosas capazes de desencaminhar moças, mesmo aquelas "de boa família" segundo o jornal, ela receitou poções amorosas e também sugeriu o uso de uma droga abortiva, se necessário, para lidar com as consequências do tresloucado amor a que induziria a moça que o jornalista disse querer conquistar. Mas o jornal logo a deixou de lado, pois ela não representava o verdadeiro alvo de O Dia, apesar do escândalo que suas atividades traziam para a moral da época.

O alvo real eram os Euzébios. E aqui não se está adjetivando esse nome próprio, mas sim aludindo a uma curiosa coincidência, que fazia com que houvesse dois Euzébios, ambos negros e curandeiros, na cidade. O primeiro deles a ser denunciado tinha um sobrenome trivial, um modesto "da Silva", mas seus traços étnicos são acentuados em ambas as reportagens: "um mulatão nédio, moço forte, que tem a sua tenda à rua 3 de maio e que atende a numerosa clientela, da qual arranca os melhores proveitos em dinheiro e os mais fartos pitéus em holocausto aos "santos" que ele tem que sustentar todas as sextas feiras...". E, no dia seguinte: "Descende[nte] em linha direta reta de pretos da África. Os seus traços étnicos são inconfundíveis: é gordo, nédio, retinto, espadaúdo, porejando fartura, confiante no êxito da vida". ${ }^{62}$ Além dessas descrições, nota-se um preconceito por essas pessoas estarem morando em casas decentes e várias alusões a sua boa vida, o que demonstra o grau de preconceito de que suas reportagens estavam imbuídas, tanto em relação às práticas como, mais ainda, em relação às suas origens raciais. Isso não era prerrogativa apenas deste jornal, mas também se notava em todos os demais da cidade, inclusive em O Rebate, que vai abrir espaço para Euzébio Coutinho Barcellos. ${ }^{63}$

62 Jornal O Dia, 18 e 19 set. 1916.

63 Especificamente sobre O Rebate, ver: CUNHA Jr. Miguel Angelo. O periódico O Rebate e a intolerância contra ciganos. Monografia (Graduação em História). Pelotas, UFPel,, 2011 e sobre o conjunto dos jornais pelotenses, ver: LONER, Beatriz. Jornais pelotenses diários na República Velha. Op. cit. 
A descrição do jornal sobre o ritual praticado em sua casa, nas "sextas feiras de holocausto", como as chamava, e com a presença de vários negros e mulatos, parecia ser de um culto afro-brasileiro com ingestão de alimentos rituais e banhos de descarrego, mas identificar suas origens não é o objetivo aqui. ${ }^{64}$ Sua casa, bem como de Constantina, são descritas como casas com certa preocupação de luxo, e seus fregueses - o repórter apressa-se em atestar —, pertencem a gente de posses.

Mas, sem apoio e sem padrinhos na sociedade, logo que saíram as reportagens, este Euzébio da Silva tratou de encerrar o expediente de curandeirismo, pelo menos por um tempo, voltando à profissão de vendedor em quiosque, segundo o jornal, que se ufanava de tê-lo derrotado.

Sendo este removido, o repórter de O Dia voltou-se confiantemente para Euzébio Coutinho. Mas então, teve uma surpresa. O “outro Euzébio" como tentou chamá-lo, disfarçando suas intenções, mostrou-se mais poderoso do que imaginavam os seus redatores. Nas reportagens iniciais sobre ele, o jornal insinua que já sabia muito de sua atuação, que se tratava de um curandeiro de "alto calibre", o "famoso" Euzébio Coutinho, muito conhecido da sociedade e cuja casa, afirmava, era frequentada por gente da própria elite que sequer se imaginaria indo consultar um feiticeiro.

O repórter o descreve como muito velho, pela barba branca, e alude a que, no passado, foi professor de danças na cidade, antes de passar a "mandingueiro completo e refinado". Confessa que Euzébio Ihe causara impressão mais forte do que os demais, com sua voz pausada, uma figura paternal e uma postura "sacerdotal", embora seu falar fosse "pernóstico, demorando-se nos SS e procurando proferir frases arredondadas, com a preocupação de se mostrar um Hipócrates em pessoa, pois, além da parte ritualesca da feitiçaria, ele exerce a medicina e a farmácia", como o provaria a beberagem que lhe fez comprar. ${ }^{65}$ Não deixa, porém, de observar que a ação de Euzébio "é preponderante sobre as pessoas católicas, pois começa de intencioná-las com uma grande cruz de metal amarelo que traz pendente da cintura, lado direito".

Ainda nessa primeira reportagem, o chama de "preto vadio e esperto" que amealhou muitas propriedades, explorando infelizes supersticiosos, pois se constitui num "madraço" de "alto calibre". Mais tarde, em pleno conflito com ele, vai promovê-lo a "bispo das bruxarias" da cidade. Deve-se notar que, naquele contexto e momento, a palavra bispo era sempre relacionada com a Igreja Católica, o alvo escondido do jornal.

Suas reportagens dizem ter o objetivo de chamar a atenção da polícia para as atividades desses curandeiros, se colocando à disposição para testemunhar e enviar as provas à omissa polícia, colocando-se na nobre missão de saneamento da sociedade, pela qual o jornal estaria recebendo muito apoio, segundo informam. A descrição da casa de Euzébio e de seu consultório é feita da seguinte forma:

No TEMPLO do mandingueiro vê-se um altar cheio de velas e santos, há também ali uma pequena mesa coberta com um pano estampado com losangos vermelhos. Sobre a mesa vê-se grandes contas com sinais cabalísticos usados na magia. Pendentes do altar há dois rosários espantosamente grandes.

64 As principais reportagens sobre Euzébio da Silva, com a descrição do ritual, saíram nos dias 20 e 21 de setembro de 1916, do jornal O Dia.

65 Jornal O Dia, 25 set. 1916. 
Em sala contígua, a severidade religiosa do templo do Euzébio é contrastada por um gramofone, cadeiras e outros móveis, tudo exposto com asseio e relativo gosto. ${ }^{66}$

A seguir, dias 26 e 27, narra como foi o atendimento de seus pretensos males, o quanto Euzébio lhe cobrou pelos serviços prestados. A crer nas reportagens, as práticas de Euzébio centravam-se em rezas católicas, benzeduras e uso de fogo e água para descobrir quem trazia o mal para seu cliente. Por fim, entregou-lhe uma garrafa com um líquido e a recomendação que tomasse três goles dela pela manhã, antes tomando colheres de azeite morno. Julgando que essa seria sua grande prova, o jornal diz que a enviou para análise. Ainda, a reportagem insinua que pessoas já teriam morrido ao tomar essas "beberragens sujas", embora fale em tom generalizante e não de Euzébio em particular.

Confiante de seu sucesso, dia 28, sob a manchete em grandes letras: "Guerra aos embusteiros e charlatãs" (sic) proclama o resultado da análise da beberagem de Constantina, em que foram detectados areia vermelha e um pó escuro, com resíduos de "ácido fosfórico, cal, traços de arsênico e de sódio", o que o jornal liga imediatamente à terra de cemitério. Bem, depois desses feitos, suas reportagens perdem o tom, porque embora tente manter a empáfia e o tom duro contra os "feiticeiros", o jornal começa a revelar as pressões que andam sofrendo de parte dos acusados e de outros setores, que não nomina.

Assim, já incomodado e pressionado pelas repercussões e ações de Euzébio, O Dia anuncia o pretenso depoimento de um vizinho, comerciante estabelecido nas redondezas, cuja mãe foi enganada por esse curandeiro. Nesse relato anônimo, afirmava-se que Euzébio fazia magia negra, com bonequinhos a serem trespassados com alfinete. ${ }^{67}$ Entretanto, embora diga que esse informante virá testemunhar "às claras" sobre o que aconteceu com sua família, isso nunca acontece, e, com isso, o jornal foi perdendo sua credibilidade. Um dos principais reveses que sofre é o resultado da publicação da análise química dos compostos utilizados pelos curandeiros, que atesta que a amostra fornecida por Euzébio não contém nada mais que cocção de ervas indígenas misturadas à canela e açúcar, sem traço sequer de elementos nocivos à saúde. ${ }^{68} \mathrm{~A}$ pouca validade da denúncia dos chás caseiros, a ausência de depoimento do informante anônimo ou a declinação de seu nome, fez com que, sem o combustível para suas denúncias, o jornal diminuísse o seu ímpeto, citando casos aqui e acolá, sem mais tentar escândalos com o agora chamado de "insolente" Euzébio.

O evidente mal-estar do jornal tem razão de ser: desde que saiu a primeira reportagem, Euzébio Coutinho tomou medidas para se proteger e desfazer o conteúdo das reportagens - ele as acusa de mentirosas e espalhafatosas - , com o objetivo de vender jornais e/ou fazer chantagem contra ele, já que a empresa estaria com suas "finanças avariadas" 69 . Para defender-se das denúncias, encontrou apoio dos vizinhos, amigos e alguns clientes que firmaram abaixo-assinado, testemunhando em seu favor, por meio do jornal O Rebate (em 28 de setembro de 1916). Também fez reuniões de apoio em salões da cidade, buscou o licenciamento

66 ornal O Dia 25 set. 1916.

67 O Dia, 4 e 5 out. 1916. O jornal apenas diz que é um comerciante respeitado do varejo e que estaria disposto a depor na polícia.

68 O Dia, 03 out. 1916.

69 O Rebate, 26 jan. 1916. 
médico na capital, além de outras possíveis ações, que se pode apenas intuir, para com padrinhos e pessoas influentes, pelos resultados alcançados. E depois, passou ao ataque,

A primeira medida foi colocar um Apedido no jornal O Rebate. Nele, Coutinho lembrava que já uma vez teve que se diferençar de Euzébio da Silva, em esclarecimento datado de maio de 1915, o qual ele republica dia 26 de setembro de 1916, acrescentando novos comentários sobre as denúncias de que foi vítima. Assim, Euzébio Coutinho primeiro se distingue de Euzébio da Silva e depois passa a discorrer sobre sua vida.

Como é o único momento em que ele sintetiza sua trajetória, vamos colocar sua visão:

Sou filho daqui, meus pais eram africanos, educaram-me conforme suas posses e conhecimentos, e eu tive a felicidade de viver sempre em perfeita harmonia nesta cidade.

Fui casado e atualmente sou viúvo, contando 67 anos de idade.

Há muitos anos venho dando instruções de danças, tendo sido os meus ensaios frequentados por muitos dignos moços, comerciantes, acadêmicos, empregados do comércio, operários, etc., e isto sempre com a máxima simpatia e respeito.

Sou conhecido pelas autoridades e pelas pessoas de minhas relações, como chefe de família e respeitador da ordem, e também proprietário nesta cidade, residindo à rua Marques de Caxias n. 470. Como cidadão brasileiro, filiei-me ao pujante Partido Republicano, desde a sua fundação.

Possuo o título de sócio benemérito de várias sociedades, sendo sócio fundador da benemérita Sociedade União Pelotense. ${ }^{70}$

Este documento é importante, pois demonstra os sinais de respeitabilidade e inserção social que conseguiu ao longo da vida e que são usados em sua defesa. O fato de ter sido escravo e filho de escravos não é tocado por ele, nem por seus detratores, o que provavelmente significa que os redatores de $O$ Dia não sabiam disso. ${ }^{71}$ Depois de colocar-se como proprietário, cidadão, eleitor, católico praticante e auxiliar da Igreja (a única associação citada nominalmente por ele, a União Pelotense, é vinculada diretamente ao Bispado e voltada para os trabalhadores), condena as reportagens pelo seu teor sensacionalista e mentiroso. Confirma que receita chás caseiros a doentes que o procuram e continua:

A minha casa está franca a devassa do público e das autoridades. Ali não há bruxarias, nem mandingas, nem feitiços, nem burundangas congêneres. Tenho um altar com os santos que venero. Isso é um direito que ninguém me pode extorquir, pois a Constituição do meu país garante a liberdade de cultos, maximé portas à dentro do meu lar. ${ }^{72}$

Neste momento, afirma que o objetivo do jornal seria fazer chantagem, extorquindo-lhe "o que tenho honestamente adquirido" e diz ter trazido até a redação de O Rebate várias pessoas que atestaram suas curas. No dia seguinte repete-

70 O Rebate, 26 set. 1916.

71 O Dia diz que Euzébio sempre viveu a vida folgadamente e sem canseiras, e o chama de malandro em vários momentos, sinal de que não sabia de seu anterior estado, pois teriam certamente explorado este elemento para mostrar o "atraso" de suas práticas, como tudo que estava relacionado ao passado escravocrata. Mesmo assim, fizeram referência à África, e, uma vez, o trataram por "preto velho".

72 O Rebate, idem. 
-se o mesmo apedido, que é modificado dia 28 de setembro, em um imenso artigo em que Euzébio ataca seus detratores. O tom é virulento, desafiador e procura atingir pessoalmente os redatores de O Dia, apelidados de "súcia de caluniadores", sinal de que havia procurado informações sobre eles. Perdoem os leitores, mas são necessárias ainda outras citações para que se compreenda a amplitude e o tom do artigo, que acusa os redatores de várias condutas impróprias, entre elas:

Saiba o João Ninguém das torturas, que me não troco por si e por toda a sua bagagem. Sou preto, mas me considero muito acima de cafajestes como esses que me estão agredindo porque não lhes quis tapar a boca com alguma nota do tesouro, de alto valor, ou com algum dos meus bens de raiz, que tanto os desespera.

Nunca andei fugido, nunca fui condenado por caluniador, nunca roubei a propriedade literária de outrem, nem andei as voltas com a polícia. Jamais fui encontrado bebendo ou nos antros de perdição, às voltas com as marafonas de ínfimo jaez, como era visto, no Rio Grande, o sevandijo que ora me ataca, procurando cuspir-me o pus da sua alma podre e repelente. ${ }^{73}$

Ao final, as acusações são ainda mais diretas e desafiadoras, em um desabafo, impossíveis de acreditar que fossem feitas por alguém que temesse alguma retaliação:

Agora, faça o mesmo o compodócio TORTURA.

Apresente, como eu, um atestado de sua conduta ou o mais leve documento abonatório das suas qualidades morais.

Farçante! Pulha!

Se ele tivesse brio, quebraria a pena que tanto tem poluído e achincaIhado, para entrar para a empresa do lixo e meter-se entre varais, único lugar que lhe compete.

Engana-se o biltre se supõe que eu me submeterei as suas diatribes. Hei de vergastal-o com a minha altivez, dizendo o que ele foi, o que é, e o que há de ser - um nulo, chato, pretensioso e charlatão, que vive sonhando grandezas, quando não passa de um...

qualquer coisa.

Pelotas, 28 de Setembro de 1916.

Euzébio de Queiroz Coutinho Barcellos.74

Obviamente, Euzébio só pôde se dirigir assim a seus opositores, porque estava bem amparado, tanto pelo Partido Republicano quanto por pessoas de suas relações na cidade e talvez pelos seus contatos em Porto Alegre. Afinal, ele tinha sido cativo de uma família importante e numerosa, que também contava ainda com ramificações variadas, dentro e fora da cidade. Soube cultivar essas relações

73 O Rebate, 28 set. 1916. Ao longo do artigo, ele insinua que um dos seus detratores esteve envolvido com a tortura, em cidade próxima, que deve ser Rio Grande. Como o estado havia passado pelo conflito oligárquico de 1893, em que a violência ocorreu de lado a lado e a cidade de Rio Grande, durante algum tempo, concentrou boa parte dos opositores a Castilhos, é possível que estivesse se referindo a algum evento lá acontecido. Mas facilmente pode também ser uma calúnia, feita apenas para desmoralizar seus antagonistas.

74 O Rebate, Idem. 
durante toda sua vida, que transcorreu dentro dos marcos da legalidade permitida. O fato de ser professor de dança deve tê-lo deixado em contato constante com as gerações de moços da elite, com quem seguramente contou num momento desses. A redação e os termos utilizados em suas respostas indicam que provavelmente foram redigidas por outros ${ }^{75}$, mas firmadas por ele; portanto, qualquer tipo de responsabilidade ou processo por difamação recairia sobre ele; não há notícias ou processos que provem que essa querela foi parar na Justiça, nem de seu lado, nem do jornal.

Seus inimigos, por outro lado, não tinham ligações fortes com a cidade e com o poder municipal. Não sendo parte das famílias da elite, sendo adversários da Igreja Católica, forasteiros com qualificação bacharelesca, e um ou dois deles com passagem pela oposição ao PRR: realmente não estavam bem municiados para o embate, mesmo com um negro ex-escravo. Não se conseguiu saber a quem Euzébio pretendia atingir com as insinuações de torturas, plágio, ou conduta imoral. Talvez nunca se possa saber ao certo se suas acusações tinham ou não razão de ser; o importante é que elas surtiram efeito: as reportagens do jornal terminaram, o delegado de polícia não tomou nenhuma providência e tudo que restou aos redatores foi, desconsoladamente, publicar uma última notícia, dia 10 de outubro de 1916, denunciando a passividade dos policiais frente à festa com foguetório e bombas reais com que foi inaugurada a placa de médico de Euzébio. ${ }^{76}$

Como resultado desse escândalo, Euzébio deve ter encontrado alguns problemas para explicar sua situação com a Igreja, mas pela própria descrição de seus inimigos fica claro que sua fama e suas práticas de culto eram todas marcadas pelo símbolo da cruz e do catolicismo. O próprio repórter não pôde descrever nenhuma estátua que não de santos católicos em seu altar e "dois imensos rosários", ainda acrescentando que Euzébio mencionava que curava em nome de São Zacarias, São Jerônimo e São Praxedes e que parecia rezar o Pai Nosso com "sinceridade"77. Assim, credenciado até pelos inimigos, Euzébio deve ter conseguido refazer seus laços com a lgreja rapidamente, pois continuara a pertencer às mesmas entidades católicas de antes.

E, para completar, já que dizia trabalhar dentro da lei, ele pede - e consegue em tempo espantosamente curto - a licença para atuar como médico, o que era permitido pelas leis do estado, conforme o artigo 71, parágrafo 5: "não são admitidos também no serviço do estado os privilégios de diplomas escolásticos ou acadêmicos, quaisquer que sejam, sendo livre no seu território, o exercício de todas as profissões de ordem moral, intelectual e industrial". ${ }^{78}$

Joaquim Osório, em Comentários à Constituição política do estado do Rio Grande do Sul, obra considerada como documento básico da doutrina castilhista, considera que a seleção de profissionais habilitados para o exercício de qualquer profissão é uma escolha do cliente e que não deve o estado interferir nessas questões, o que configuraria uma "tirania revoltante", especialmente no caso particular da medicina. O que cumpre ao estado é zelar para que não haja possibilidade de fraude ou engano do profissional para com seu paciente e cuidar de punir a quem,

75 Do próprio punho de Euzébio tem-se sua assinatura, no inventário da esposa, que indica falta de familiaridade com a escrita, pelo menos.

76 O Dia, 10 out. 1916. Remoído pela raiva, o redator menciona uma festa "com bródio e vinhaça", mas, pode-se imaginar que isso corre pelo seu ressentimento, pois seguramente foram servidos finos doces pelotenses e vinhos estrangeiros, além de cerveja, comprados nos melhores estabelecimentos da cidade.

77 O Dia, 25 set. 1916.

78 OSORIO, Joaquim. Constituição política do Estado do Rio Grande do Sul: um comentário. Brasília: EdUNB, 1981, transcrição da constituição do estado, artigo 71, parágrafo 5. 
com suas práticas, levar terceiros ao agravamento do estado de saúde, mostrando imperícia ou ineficácia. Após relembrar que ocorrem centenas de erros médicos, afirma que o médico diplomado tem apenas a presunção de seu saber, o que nem sempre é comprovado. Por outro lado, os curandeiros são perseguidos, pois se considera que são sempre ignorantes. Contudo, diz ele, "é certo que tem havido e há grande número deles [curandeiros] práticos, experientes admiravelmente dotados de poder observador e que tem descoberto na nossa flora preciosas plantas medicinais". Após lembrar que no Brasil boa parte de sua população vivia nos campos, locais onde não existiam médicos e onde os curandeiros eram o derradeiro "recurso das populações, para os quais voam as esperanças dos aflitos. Podem dar disto eloquente exemplo os sertões de minha terra natal". ${ }^{79}$ Ora, a terra natal do ilustre advogado e político, descendente da família do General Osório, era a cidade de Pelotas. Portanto, conhecia bem sua zona rural, suas charqueadas, com seus usos e costumes. Provavelmente até conhecesse Euzébio como professor de danças, pois morou em Pelotas em sua infância e juventude.

Daria um outro artigo o deslindar da complexa rede que Euzébio acionou para conseguir vencer os brancos redatores e os cultos bacharéis de O Dia. ${ }^{80}$ Ele foi o único a vir a público e desafiar seus oponentes, apelando para a liberdade de culto e para sua posição de cidadão brasileiro. Uniu, a seu favor, posições conflitantes, pois, se encontrou espaço no oposicionista jornal O Rebate para veicular suas respostas, também acionou seus contatos no governo. Talvez, quem sabe, teve um auxílio a seu favor do coronel Aurélio Veríssimo de Bittencourt (afrodescendente porto-alegrense e devoto de Nossa Senhora do Rosário, que, em 1916, ainda ocupava o cargo de secretário particular do governo Borges de Medeiros), o que lhe valeu a velocidade com que sua licença foi concedida pelo governo. Isso é algo ainda a ser comprovado, mas o importante é que está dentro do território do possível, dada a rede de relações e amizades que montou dentro e fora da Igreja e do PRR.

E, com isso, consolidou-se a vitória em todas as frentes de Euzébio. Vitória não discreta, tanto que ele afronta mais uma vez seus inimigos (e, possivelmente, o delegado...), ao fazer uma comemoração em regra, com banda, dança, comes e bebes. Nesse momento, foi saudado efusivamente pela comunidade afrodescendente, embora a notícia abaixo seja extremamente contida, não falando nos foguetórios, brindes e comidas que compuseram a festa. O jornal A Alvorada era o porta-voz da comunidade negra e um certo recato frente ao sucesso fazia parte do modelo de bom tom da época, pelo menos na sociedade pelotense. Assim, o título da notícia é um despretensioso "festa íntima", com o objetivo de reforçar a respeitabilidade do grupo (note-se que, em nenhum momento anterior, o jornal comentou a polêmica e as denúncias contra Euzébio):

Foi imponente a festa íntima realizada domingo passado, na residência do senhor Euzébio de Queiroz Coutinho Barcellos, em regozijo do recebimento de sua carta de médico. Foi cumprimentá-lo a Filarmônica União Democrata e um avultado número de amigos. Encerrou a festa um sarau dançante, que prolongou-se até altas horas da madrugada. Mais uma vez felicitamo-lo. ${ }^{81}$

79 Idem, ibidem, p. 243.

80 Em uma última reportagem (10 out. 1916), O Dia faz algumas insinuações, a propósito da comemoração: "o famoso mandingueiro Euzébio, que festejou a impunidade e a frouxidão do Sr. Cristovão dos Santos [delegado de polícia] anteontem, com dúzias e dúzias de foguetes de lomba (sic) real, alguns deles, aliás em homenagem ao sr. Promotor público da comarca..."

81 A Alvorada, 15 out. 1916, p.2. 


\section{O espaço mina na cidade}

Mas há um último elemento que deve ser levado em conta na história desse personagem, o qual remete novamente à escravidão: sua origem, o local onde se criou e o fato de que era considerado "mina". Seus parentes, bem como a maioria do lote de escravos da charqueada do Comendador Barcellos, por ocasião de seu nascimento, era de africanos e seus descendentes e, entre eles, os nagôs, também chamados minas, eram a maioria. Sua mãe era Nagô, Cosme era nagô e vários outros pretos velhos eram "mina", que, para a cidade, tinham o mesmo sentido que nagô. Sabe-se que o termo mina teve muitos usos no Brasil e variou no tempo e no espaço. Segundo Scherer ${ }^{82}$, minas e nagôs, combinados, formaram a maioria dos plantéis dos estabelecimentos empresariais da vizinha cidade de Rio Grande, e, por extensão, pode-se dizer o mesmo de Pelotas, pois todos os trabalhadores escravizados entravam por esse porto marítimo.

Crescendo na charqueada, Euzébio deve ter se beneficiado de conhecimentos ancestrais dos africanos de varias paragens, bem como da farmacologia de eventuais índios ainda existentes na região. Seu espírito, voltado ao misticismo e à religião, características que o acompanharam por toda a vida, deve ter se interessado pela aprendizagem dessas receitas, que depois utilizava em suas curas (recorde-se a análise química dando conta de cocção de "ervas provavelmente indígenas", do laudo do laboratório sobre suas poções de cura).

Não é objetivo aqui a análise de suas sessões de cura ou dos remédios que empregava, o que serve apenas para demonstrar que, em sua vida republicana, Euzébio também se utilizou de suas vivências e experiências anteriores, as quais, em parte, haviam sido "esquecidas" pela comunidade negra urbana pelotense. Mesmo profundamente entrosado no contexto social do século XX, Euzébio ainda cultivava os traços das experiências dos africanos que mais o interessavam. Seguramente não foi à toa que ele e seu irmão, juntamente com outros negros oriundos de antigas charqueadas (conforme dedução possível a partir dos patronímicos que utilizaram), fundaram uma sociedade que ainda relembrava os africanos, como se viu acima. Para Euzébio e outros ex-escravos, o Brasil da modernidade e da integração ao capitalismo industrial, sonhado e louvado por todos, no início do século XX, ainda podia se beneficiar de práticas mais antigas, mesmo que de forma camuflada.

A este respeito, fica como curiosidade o relato de que, quando os autores deste artigo estavam buscando por memórias sobre Euzébio na cidade, ficaram sabendo que, durante o século XIX e XX existiu em Pelotas um espaço constituído por algumas ruas perto do porto, chamada hoje Zona da Balsa, ocupadas preferencialmente por africanos dessa procedência. A menção do nome de Euzébio Coutinho Barcellos, para um idoso afrodescendente, ainda provocou inquietação, acompanhado da pergunta sobre por que queríamos saber dos "minas" na cidade. Infelizmente, nada mais se quis falar sobre esse assunto, embora várias vezes fosse procurado.

Seu receio retorna a questão de temores do passado. Segundo Juliana Farias, no Rio de Janeiro durante o período imperial, os minas tinham o domínio da venda de feitiços aos brancos, que os temiam. Essa autora, por meio das crônicas de João do Rio, articula a procedência mina (variada e genérica também naquela província) ao comércio de feitiçarias, benzeduras e outras práticas, com grande sucesso. ${ }^{83}$

82 SCHERER, Jovani. A nação da liberdade: os minas e outros grupos...

83 FARIAS, Juliana. Mercados Minas. Africanos ocidentais na praça do mercado do RJ (1830-1890). São Paulo, USP, 2012 Tese (Doutorado em História). p. 267/268. 
Em todo o Brasil Império, houve uma aura sobre o "preto mina", normalmente considerado ardiloso, capaz de muitas formas de resistência e pessoa a qual tanto os outros negros como os brancos temiam. Segundo Chalhoub, no Rio de Janeiro se consolidou a história do liberto mina como agente que seduzia os demais escravos a se deixarem vender para outros senhores, o que poderia ser uma forma de buscar um cativeiro menos duro ou reencontrar as pessoas amadas. ${ }^{84}$ Sabe-se que os minas ou nagôs, quase que em toda parte, conseguiam libertar-se mais frequentemente do que os escravizados de outras etnias.

Euzébio, como descendente desse grupo e do qual nunca se desligou, teve êxito em sua função de curador também por causa de sua ascendência e, provavelmente, dos segredos que trazia do cativeiro. A análise do chá caseiro que passou ao repórter (que deveria ser combinada com a ingestão de "azeite doce" aquecido) deixa claro que muito havia de sabedoria negra e indígena em suas práticas, as quais, por outro lado, se acoplavam a uma visão bastante espiritualizada da medicina, considerando que não era apenas o corpo, mas também o espírito, que devia ser curado em caso de doenças. Segundo J.J. Reis, "a farmacopeia nagô-iorubá... é riquíssima em folhas tanto para ataque, quanto para proteção, para beneficiar e prejudicar..." 85

Cabe, ainda, uma palavra final sobre esta personagem e ela vai ser feita no plural: a análise da trajetória de Euzébio nos custou muito tempo e foi feita com muito cuidado por todos os integrantes da equipe. Isso não significa que fomos motivados apenas pela curiosidade, ou pelo afã de demonstrar a trajetória de um indivíduo com um perfil oposto ao que se espera de um ex-escravo de charqueada. $\mathrm{Na}$ verdade, o personagem é fascinante por si mesmo e, embora no início tenha sido desprezado, porque não era "proletário", quando o foco recaiu sobre ele, foi fácil desenvolver uma grande empatia por ele, ao observar suas artimanhas, suas formas de contornar situações extremamente desfavoráveis para impor seus interesses, desenvolvendo uma trajetória impar.

Euzébio demonstra uma mistura de inventividade e audácia, combinada com modéstia e discrição, que tornou viável sua trajetória. A maior lição de Euzébio foi ter conseguido impor-se naquela sociedade, por suas qualidades e por ser sagaz e astuto. Como ele, outros ex-escravos viveram durante a Primeira República e lutaram por melhores condições de vida para seu grupo, em alguns casos para a classe operária, e, em última análise, para eles próprios e para suas famílias. A reconstituição dessas múltiplas histórias, tanto as que deram certo como as que falharam, é fascinante e deve ser feita pelos historiadores de todo o Brasil, pois essa não é uma questão local.

O objetivo desses estudos, em nosso entender, é o de, em alguns anos, se ter uma ideia melhor de como homens e mulheres negros, libertos do fantasma da reescravização e de suas consequências a partir de 1888 (e apesar de tudo o que se possa falar da precariedade da liberdade nos "tempos modernos" do capitalismo) lutaram para viver e adaptar-se às novas condições de vida. Ao longo das décadas da Primeira República, algumas vezes venceram, na maioria dos casos foram empurrados para trás, pela sina do operariado no Brasil e pela frustrante e presente discriminação racial que sempre os atingiu. Mas, ao fim e ao cabo, não foram pobres coitados, incapazes de viver por si mesmos. Buscaram oportunidades e empregos, aproveitaram ocasiões e padrinhos, lutaram e militaram alguns,

84 CHALHOUB, S. A força da escravidão. Op. cit., p. 155 e seguintes.

85 REIS, J. J.. Domingos Sodré, um sacerdote africano. Op. cit., p. 152. 
nas sociedades operárias. Milhares se conformaram, alguns tiveram momentos de glória, outros reconheceram-se derrotados. Mas, enfim, sempre tentaram melhorar de vida, tal como os brancos, tal como o operariado comum. Para não deixar de citar Thompson ${ }^{86}$, mesmo que na última frase, nesse sentido, não precisam da comiseração ou condescendência de nossa parte, precisam é de mais estudos.

Recebido em 08/02/2013 Aprovado em 7/06/2013 
